\title{
Transatlantica
}

Revue d'études américaines. American Studies Journal

\section{A New American "Physical Morality": Martha Graham and the Revaluation of the Body in Letter to the World}

\section{Adeline Chevrier-Bosseau}

\section{OpenEdition}

\section{Journals}

Electronic version

URL: https://journals.openedition.org/transatlantica/15341

DOI: 10.4000/transatlantica.15341

ISSN: 1765-2766

Publisher

Association française d'Etudes Américaines (AFEA)

Electronic reference

Adeline Chevrier-Bosseau, "A New American "Physical Morality": Martha Graham and the Revaluation of the Body in Letter to the World", Transatlantica [Online], 1 | 2020, Online since 01 December 2020, connection on 31 January 2023. URL: http://journals.openedition.org/transatlantica/15341 ; DOI: https://doi.org/10.4000/transatlantica.15341

This text was automatically generated on 31 January 2023

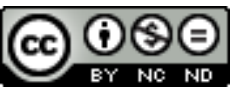

Creative Commons - Attribution-NonCommercial-NoDerivatives 4.0 International - CC BY-NC-ND 4.0 https://creativecommons.org/licenses/by-nc-nd/4.0/ 


\title{
A New American "Physical Morality": Martha Graham and the Revaluation of the Body in Letter to the World
}

\author{
Adeline Chevrier-Bosseau
}

1 Reminiscing about the days she spent reading "everything that had ever been written on the Art of Dancing" in the library of the Paris Opera in the Palais Garnier, Isadora Duncan came to the following conclusion: "I realised that the only dance masters I could have were Jean-Jacques Rousseau ('Emile'), Walt Whitman and Nietzsche" (Duncan 65). Decades later, another pioneer of modern American dance, Martha Graham, also credited Nietzsche as one of her dance masters: "I owe all that I am to Nietzsche and Schopenhauer" (Stodelle 38). Nietzsche, whose definition of a noble education was "being able to dance with the feet, with concepts, with words" (Nietzsche, 1968 VIII 7), is probably the philosopher in whose work dance has the most prominent place. As Kimerer Lamothe notes:

On the pages of Nietzsche's texts, multitudes dance. Dionysian revelers, satyrs of the tragic chorus, and Dionysus himself; medieval Christians, free spirits, inspiring muses, and Zarathustra; gods and goddesses, young girls, women, and higher menall dance. So do thoughts, words, pens, stars, and sometimes even philosophers. The dances performed are as diverse as the performers, differing in rhythm, style, context, and meaning. Nietzsche uses Tanz or "dance" to describe the activity that occurs during Greek festivals, satyr plays, and Attic tragedies; in the Bible and in Christian history; in social settings and crowds. Dance appears as art, religion, and recreation; as a discipline, a language of gestures, and an experience of rapturous intoxication. In nearly all of Nietzsche's books, from Birth of Tragedy to Ecce Homo and the posthumous Will to Power, images of dancers and dancing appear with remarkable consistency (Lamothe, 2006 1).

2 The Dionysian liberation of the body in dance that appears in Nietzsche's works, his representation of dance as a "language of gestures," and his conception of morality that does not exclude the body-as a more Cartesian current in philosophy tends to do 
-all spoke deeply to Graham and Duncan. Both women were born in rather educated families-albeit differently so ${ }^{1}$-and although they eschewed an academic education in favor of a dance education, ${ }^{2}$ they remained intellectually curious all their lives and were both avid readers. Their intuitive, organic approach to dance ${ }^{3}$ is mirrored in their intuitive and very personal approach to literature and philosophy, which isn't any more academic than their dance styles are. Like her predecessor Duncan, Graham was also profoundly inspired by Nietzsche in her own revaluation-Umwertung-of American Puritanism: the dancer and choreographer, who called dancers "athletes of God," saw dance as a way to explore and revaluate the Puritan relation to the body, and particularly to female bodies. Born in Allegheny (Pennsylvania) at the end of the $19^{\text {th }}$ century, Graham and her two sisters were raised in a largely female household composed of her mother, her maternal grandmother and her nanny-the only men being her father and a younger brother who died in infancy. Graham's mother was a proud descendant of Mayflower pilgrims, and religion occupied a prominent place in the Graham household. ${ }^{4}$ The Puritan mindset of her mother's ancestors was driven deep in Graham's psyche from a very young age, and she soon rebelled against the numerous constraints this Puritan mentality imposed on women, both physically and psychologically. Throughout her career, Graham choreographed ballets that featured women torn between their desire to live and love freely and the constraints imposed by society and patriarchal conventions. A tireless pioneer, she explored movement and the American history, territory, and culture in search of the best way to express what she perceived to be the American soul in dance. This paper will explore Graham's revaluation of American Puritan morality, and her Whitman-inspired conception of a physically embodied American democracy, as well as the way Nietzschean Umwertung is enacted in her ballet Letter to the World, which was inspired by the life and work of Emily Dickinson.

\section{"Free, joyful action": Martha Graham and the Revaluation of American Morality}

3 In The Genealogy of Morals, Nietzsche opposes the "priestly-noble mode of valuation" to what he calls the "knightly-aristocratic" values that promote "a powerful physicality," whereas "priestly" values lean towards repression, self-hatred and vengefulness. For Nietzsche,

the knightly-aristocratic value judgments presupposed a powerful physicality, a flourishing, abundant, even overflowing health, together with that which serves to preserve it: war, adventure, hunting, dancing, war games, and in general all that involves vigorous, free, joyful activity. The priestly-noble mode of valuation presupposes, as we have seen, other things [...]. It is because of their impotence that in them hatred grows to monstrous and uncanny proportions, to the most spiritual and poisonous kind of hatred (Nietzsche 1989 VII 33).

4 Early ballets by Graham, like Heretic (1929), American Provincials (1934), El Penitente and Letter to the World (both 1940) ${ }^{5}$ enact this opposition between a frozen, life-crushing Puritan energy and an impulse towards "vigorous, free, joyful activity." Graham grew up in a milieu that was rife with references to American Puritanism, and when she recalls the family's move to California when she was in her teens, she opposes the Puritan East, a symbol of her past, to the freer, future-oriented West (Graham 1991 43-44). Graham's conception of American Puritanism is a combination of her education 
(her knowledge of American history and of the "Founding Fathers"), the legacy of her family and upbringing (which is directly referred to in Letter to the World through the character of the Ancestress), and her own fantasies and personal struggles with what she perceives as Puritan in the American mentality (the repression of the body, feelings of shame and guilt-especially regarding sexuality ${ }^{6}$ ). The notion of Puritanism thus crystallizes for Graham not only the historical Puritanism she was taught about in school, combined with a web of cultural references to Early America and the Puritans that abound in the American collective imagery, but also a more diffuse sense of an intrinsic Puritan streak that she felt endured in the American mentality. Many of her ballets therefore reenact scenes of the Puritan repression of women that have become part of the collective American imaginary on Puritanism, such as the Salem witches' trials or Nathaniel Hawthorne's references to Puritan gloom. Danced only by women, Heretic and American Provincials oppose a soloist to a group that judges and rejects her: in these two ballets that enact a religious divergence (the soloist being the "heretic"), the opposition between a single female and a condemning mob is reminiscent of Hawthorne's Scarlet Letter and the treatment of Hester Prynne by the Puritan community. ${ }^{7}$ Throughout her career, Graham extensively explored this opposition between the two forces of Puritanism (which is always represented as deadly) and the affirmation of life and joy. The Nietzschean opposition between "vigorous, free, joyful activity" and the "impotence" of priestly values resonated so deeply with Graham that she even included a reference to this passage from The Genealogy of Morals in the program handed out during the 1929 performance of her solo Danza. ${ }^{8}$ This performance was part of a triple bill, along with Resurrection and Adolescence; the review printed in The New York Times on March 4, 1929 shows how Graham's resistance to conventions was met with perplexity at best, or rejection, by critics. The author of the review praises Adolescence for being "the happiest use Miss Graham has made of her economy of movement, and perhaps the least inclined in the direction of ugliness," and writes about Danza that "its interest lies in its impression of dance movement where there is actually only the barest skeleton of such movement. Of the three it is the least intriguing on first view." Rejecting-like Duncan before her-the stifling conventions of ballet, Graham's purpose was to explore movement to reveal the truth of the body, as "ugly" as it may seem to spectators conditioned to appreciate more classical forms of dance; to many people, she was, as she puts it herself, "a heretic." In her autobiography, Graham recalls a conversation she had after her first solo performance in 1926 with a female spectator "dressed as a woman of the late nineteenth century" who thought her dance was "simply dreadful":

The response of Miss Ruth's friend ${ }^{9}$ was typical. To many people, I was a heretic. A heretic is a woman who is put upon in all she does, a woman who is frightened. Every place she goes she goes against the heavy beat and footsteps of those she opposes. Maybe she is a heretic in a religious way, maybe in a social way. I felt at that time that I was a heretic. I was outside the realm of women. I did not dance the way people danced. I had what I called a contraction and a release. I used the floor. I used the flexed foot. I showed effort. My foot was bare. In many ways I showed onstage what most people came to the theatre to avoid (Graham, 1991 114).

Graham made extensive use of "heretic" technique, with flexed feet, hunched torsos, off-center tilts, along with a refusal to portray the female body as a light and ethereal being floating on stage (as it usually appears in the ballet tradition), but on the contrary a desire to work with body weight, gravity, and using the floor. Like many other dance pioneers (Ted Shawn or Isadora Duncan, for example), she was inspired by 
Walt Whitman's vision of America and his conception of physicality in her own search for the truth of the body. Whitman was a "spiritual father" 10 to many of the pioneers of American dance, who all adopted an idealized, romanticized vision of the American poet as the great formal innovator and liberator of the American body-a template for revolutionary art that does away with obsolete conventions and wants to create a new and free American self; many of these pioneers of what could be called the American Renaissance in dance, no doubt inspired by Whitman's sweeping enumerations and strong lyric energy, had a very grandiose vision of the poet's art and of what innovative American art should be. ${ }^{11}$ In Leaves of Grass, Whitman celebrates the body's unaffected beauty, its vitality and strength; he sings the sacredness of the body, as in this famous passage from section 6 of "I Sing the Body Electric": "The man's body is sacred, and the woman's body is sacred; / No matter who it is, it is sacred" (84). Critic Jimmie Killingsworth writes that

Whitman considered health to be a matter that involved the whole self-the physical, moral, and psychological being. Indeed, at times he seems to equate the three. With his physical morality, Whitman hoped to instill in his audience a new awareness of personal beauty, of bodily needs, of the importance of the individual (Killingsworth 15).

6 Like Whitman, Graham strove to redefine physical beauty: in classical ballet technique, pointe shoes are used to create the illusion of lightness and ethereality, as if the female dancer was floating effortlessly on stage, but Graham wanted to show the truth of the body in motion-as she says herself, she "showed effort," showed tension, broke classical lines to create new ones in an endeavor to present organic and true movement. In this sense, her quest is much akin to Whitman's as depicted above by Killingsworth: she wanted her audience to rethink what "ugly" and "beautiful" movement was, and to find the sacred beauty of the body in all movement, and in the physicality, the muscular strength of the human body. Everywhere in Leaves of Grass Whitman praises the strength of physically active bodies. ${ }^{12}$ Graham's "physical morality," like Whitman's, rejects the social oppression of the body and of human sexuality, the fakeness of conventions, and looks for the purest expression of human movement. As she often famously said, "Movement is the one speech which cannot lie" (Armitage 99) ${ }^{13}-$ a statement that was inspired by what she calls her "first dance lesson" taught by her alienist father, who told her that she must always "look for the truth" (Graham, 1991 19-21). The body is the ultimate locus of truth, since, according to the principles of Delsarte that inspired her ${ }^{14}$ the body doesn't lie; a person can lie in various ways, through speech, costume, actions, but the body will always reveal the truth. This conception of the body, inherited from her father and the influence of Delsartism, has shaped Graham's conception of dance throughout her entire career, which she describes as "a gesture toward the truth" (Graham, 1991 20). Graham's "physical morality" relies on discipline and mindful practice: as she explains in her "Primer for Action" destined to dancers, "freedom may only be achieved through discipline [...]. Your years of training and discipline in your craft and in the cultivation of yourself as a human being have made it possible for you to be free" (Graham, 1941 178-87). Influenced by Zen Buddhism and Jungian psychoanalysis, Graham built a technique that advocated a strong mind-body connection, in accordance with these principles. As Mark Wheeler explains in his article on "The Orient in America: Fertile Soil for Martha Graham," 'by mentioning 'spontaneity,' 'freedom' and 'simplicity' as desired qualities of the dancer and in identifying discipline as the only way to achieve 
them [she] echoes Suzuki in the following instance addressing the 1957 Conference of Zen Buddhism and Psychoanalysis in Cuernavaca, Mexico" (Helpern 49).

The body and the mind are perfectly indissociable for Graham. In her notes for her ballet Death and Entrances, Graham reflects on the physicality of the struggle between light and darkness, between the "real being of good, of creative energy" and the "powers of darkness" which she presents in Puritan terms as a "witches' Sabbath." This struggle, represented through dance in her ballet, is a physical one: "Strength comes from a use of the muscles-the athletes of God wrestled and grew strong. They chose, \& they acted. What I do must be done in full sunlight of awareness-I must learn a means of changing the mood-the state of consciousness-without double-mindedness or tho't of gain" (Graham, 1973 87). Virtue and strength therefore lay with the body, not the mind alone, in a very Nietzschean revaluation of the place of the body. For Graham, the morality-truth and virtue-of the American body also meant exposing the truth of its origins, and acknowledging its Native roots. While Puritan anti-dance writings presented dance as disorderly, and equated it to savageness and the devil, ${ }^{15}$ Graham rejects this "priestly mode of valuation" and its mortification of the flesh in favor of a celebration of moral physicality that embraces the "savage" and the "primitive" in her quest for the true roots of American spirituality. In her captivity narrative, Mary Rowlandson represents the ritual dances of the Indians as a hellish vision: "This was the dolefulest night that ever my eyes saw. Oh the roaring, and singing and dancing, and yelling of those black creatures in the night, which made the place a lively resemblance of hell"16 ("First Remove," Rowlandson 8). Similarly, in Hawthorne's short story "The Maypole of Merrymount," the dancers (who will eventually be reprimanded by the Puritans and forced to conform to their values) wear clothes and adopt attitudes and movements that make them look like beasts or savages. ${ }^{17}$ In her quest to find true indigenous American movement, Graham explored Native American movement in depth; though in her own admission she "never [did] an Indian dance" (Graham, 1991 176), having always refused to create imitative art, Native American movement was profoundly inspirational to her technique, ${ }^{18}$ and she retained the energy and spirit of Native American dances ("I've received an excitement and a blessing and a wonderment from the Indians," Graham, 1991 176), which she identifies as a celebration of life. ${ }^{19}$ Ballets like Primitive Mysteries (1931) or El Penitente (1940) draw from Native American ritual dances as well as from medieval mysteries to depict the mystical union with the divine. Both ballets are quite minimalistic in form, replicating the starkness of what could be construed as Puritan aesthetics, but this simplicity is profoundly infused with vitality and joy-notably in the group dances that take on a festive air. Set in the Native rituals of the American Southwest, El Penitente was built like a Medieval mystery play, and retains some of its austerity in the simplicity of the choreography, along with moments of joy and humor: scenes of penance and flagellation are followed by a joyful group dance, and, as Jack Anderson notes in his October 10, 1989 review of the piece for The New York Times, the ballet features "sly touches of theological humor, as when the wiggly Mary Magdalen tempts the Penitent with a piece of fruit, thereby recalling Eve's temptation of Adam." In his review of Primitive Mysteries, dance critic John Martin ${ }^{20}$ writes that the ballet "communicates with complete persuasiveness the ritual integrity of a religious people who have welcomed the young gods of the white man into the company of their own ageless Indian deities of earth and sky." Graham's combination of Native and Christian references, of primitiveness, of Eastern and Western cultures, recalls the cosmopolitan whirl of 
dances depicted in the fourth section of Whitman's "Proud Music of the Storm" (342-43): like Whitman, who presents all types of dances-Eastern and Western, "barbaric" and "civilized"-with no cultural nor aesthetic hierarchy whatsoever in this section of the poem, Graham seeks to celebrate the universality of physical expression, the sacredness of every human body which offers itself in worship through dance. ${ }^{21}$

By combining Native American and Christian rituals, Graham explores the roots of American spirituality, between the Puritan impulse towards rigidity and the Native urge towards physicality and joyful energy. Taking the raw, wild, and unrestrained energy of Native American dance and integrating it as the "primitive source" (Armitage, 100) of American dance (along with African-American dances), Graham unearths the origins of American movement, thus rejecting its affiliation with the European tradition ${ }^{22}$. As Mark Franko explains in his article "Emotivist Movement and Histories of Modernism: The Case of Martha Graham," Graham thus rejected imitative dance, which she associated with the European ballet tradition: "Graham's writing during this period also embroils imitation (to be avoided) and unique presence (to be fostered) in a convoluted symbolism of male and female roles. Seeking the indigenously American, Graham was led to eschew imitative dance which she linked to European ballet and its reputation for effeminacy" (Franko, 1991 117).

If dance is "the affirmation of life through movement" (Armitage, 103), then it is not imitative, but life itself; for Franko, "the intention of this work is to remain at the origin of presence, not at the origin of meaning" (Franko, 1991 118). This definition of Graham's intention recalls Archibald McLeish's contention that "A poem should not mean / But be" in the final lines of his Ars Poetica: Graham's ars choreographica is a celebration of life, of its vitality and constant renewal. In her rejection of imitation, Graham also rejects the artificially feminine, and the association of femininity with imitation instead of original creativity. For Graham, "virile gestures are evocative of the only true beauty. Ugliness may be actually beautiful if it cries out with the voice of power" (Armitage 97). In her 1930 essay "Seeking an American Art of Dance," Graham identified the American creative urge as masculine: "Although she may not yet know it, America is cradling an art that is destined to be a ruler, in that its urge is masculine and creative rather than imitative" (Graham, 1930 249). The passage showcases Graham's complex conception of the virile feminine: America is seen as female (through the use of the pronoun "she" and the representation of motherhood, America "cradling" the art of dance) but engendering a strong masculine force. This representation is echoed in the conception of her female roles, strong women who do not "act feminine," whose power and strength is their main feature, and who are driven by a "masculine" force and willpower. Graham pioneered a particular brand of maieutics in her technique: for her, the truth of female movement originates in the pelvis. In her trademark contraction and release technique, the contraction comes from the pelvis, which becomes for her the locus of truth and of emotions in the body ${ }^{23}$. In her autobiography, she explains that this aspect of her teaching was so groundbreaking that her students had nicknamed her school the "house of the pelvic truth":

I know my dances and technique are considered deeply sexual, but I pride myself in placing onstage what most people hide in their deepest thoughts. Emily Dickinson in her own proper way said that all of us have moments "when shy humiliations gambol on sunny afternoons, who is to say not to do it." The artist is simply reflecting his time. [...] It bemuses me that my school in New York has been called "the House of the Pelvic Truth" because so much of the movement comes from a 
pelvic thrust, or because I tell a student "you are simply not moving your vagina"

(Graham, 1991 211). their inner virility: it encourages them to dig deep within themselves to find what Franko calls this "feminine masculinity" (Franko,1995 56) which is so idiosyncratic to the Graham technique. Martha Graham's choreographic writing can be associated with an écriture feminine, as defined by Cixous, Showalter or Irigaray, in the sense that the origin of movement is the female body: as we saw earlier, with the affirmation of dance as life itself and as a celebration of perpetual inchoation and rebirth, combined with the definition of the pelvis as the origin of movement and of Grahamian maieutics, Graham explores her own way of "writing female" and contending with masculine forces. All her ballets explore female sexuality, female movement, female physicality and strength, but one of the most telling examples is her ballet inspired by poetess Emily Dickinson, entitled Letter to the World.

\title{
Nietzschean Umwertung in Letter to the World
}

\author{
If my virtue is a dancer's virtue, and I have often leaped with both feet into golden- \\ emerald rapture: \\ If my wickedness is a laughing wickedness, at home under rose-bowers and hedges \\ of lilies: \\ -For in laughter is all evil compacted, but pronounced holy and free by its own \\ blissfulness:- \\ And if this is my Alpha and Omega: that all that is heavy become light, all body \\ become dancer, all spirit become bird-and verily, that is my Alpha and Omega!- \\ (Nietzsche, 2005 202)
}

Danced for the first time in the Bennington College Theatre in August 1940, and performed for the first time in its definitive version in New York City in January 1941, Letter to the World is part of the group of pieces known as Graham's "American" ballets, like American Document, Frontier or Appalachian Spring. The ballet is divided into five acts, and alternates scenes exploring the interior life of Dickinson and others representing her public persona-all in non-chronological order, to evoke an oneiric temporality, and also possibly the universality of the struggle against the Puritan repression featured in the ballet. In the program, Graham states that the piece is based on the "legend" of Emily Dickinson, not on the facts ${ }^{24}$ : this is doubly true since the only edition of Dickinson's poems that was available when Graham choreographed the ballet was the Higginson and Todd edition-a highly controversial one that had given titles to Dickinson's poems and erased all her poetic "quirks" as to grammar, spelling or punctuation. This edition and the representation her first editors gave of the poetess is largely responsible for the enduring "legend" of Emily Dickinson as a recluse and weird poetess who withdrew from the world because of a broken heart. Critic Edwin Denby refers to this legend in his review of the ballet: "There is a legend that Emily Dickinson fell in love with a married minister, whom she saw once or twice and might have run away with" (Denby 54). This legend is what underscores Graham's ballet as well, as visible in the program: "the loss of her lover forces her to face her destiny as a poet with the realization that her happiness must be found in the intensity of her work. That out of the tragedy of loss will be born the poet, is her "Letter to the World"' (program for Letter to the World, 1941). Beyond the cliché of the lovesick spinster, Graham took this limiting legend and turned it into a portrayal of the female artist's fight for 
freedom: her fight against Puritan values in her experience of love and desire, and her fight to find her voice as an artist in a stifling environment.

The ballet stages the overturning of values-Umwertung-that Nietzsche's Zarathustra pleads for in the chapter entitled "Old and New Tablets" with the anaphora "shatter, shatter the old tablets" (Nietzsche, 2005 170-188): the considerable violence exerted against the female artist, the mortifying Puritan and patriarchal yokes, must be fought and overturned. During the course of the piece, the heroine struggles against various adverse forces to impose her own values, to liberate herself through the dance like Zarathustra the dancer. In Nietzsche's seminal work, dance repeatedly stands for freedom and joy-the quintessential life force and form of resistance against deadly values that need to be vanquished. In Letter to the World, the two driving forces, desire, the affirmation and celebration of life, and the artistic creative impulse, are represented by the main character being split into two Dickinsons, "The One who Speaks" and "The One who Dances." The program explains that

no one character [...] is meant to portray Emily Dickinson-each character is some aspect of her. "The Children," "The Fairy Queen" and the "Young Girl," as well as the "One who Dances" and the "One who Speaks" are extensions of her own self in childhood, adolescence and maturity. "The Ancestress" is the embodiment of her background, puritan, awesome, but beautiful and is the symbol of the death-fear constantly in her mind. "March" and the other men are extensions of the "Lover" who, in turns, represents her gesture toward happiness" (program for Letter to the World, 1941).

We can see here another example of Graham's "feminine masculinity," since-if each character is a facet of Dickinson's personality-the male figures are facets of her character, the virile, masculine driving force that Graham identifies as the creative urge within the female creator. The ballet unfolds to a score by Hunter Johnson, and to the rhythm of the 36 poems recited by "The One who Speaks." The first act, "Because I see New Englandly," presents the two Emilys in Amherst: it opens on a tableau in which "The One who Dances" is sitting on a bench while "The One who Speaks" comes on stage reciting "I'm Nobody! Who are you?" This poem has often been read as the "proof" that Dickinson voluntarily shrank from publication in a Victorian display of modesty, refusing to expose herself publicly "like a Frog." It attests to the ambiguity of Dickinson's relationship to publication, and to the extent to which Puritan conventions had been internalized by the poetess; although she wrote to Higginson presumably to seek advice in the perspective of publication, she also repeatedly proclaimed that this was not her intention. The "refusal" to publish expressed in "I'm Nobody! Who are you?" testifies to the unshakable and overwhelming weight of Puritanism and Victorian conventions which urged women not to expose themselves in the public sphere, instilled in them a disgust in seeing their works passed on from one editor to the next and from one reader to the next-where the public handling of the textual body echoes an inappropriate handling of the physical body. Another form of repression of the woman writer was that enforced by the patriarchal literary canon, incarnated in Dickinson's life by her father and by her "mentor," Thomas Wentworth Higginson, to whom she had written in 1862 asking for advice on her poems, and who performed, as she put it, "surgery" on her texts. ${ }^{25} \mathrm{He}$ thus quickly made her understand that publication was not an option. ${ }^{26}$ Emily Dickinson was ambivalent as to publication, at once attached to her native region and her home and eager to exist outside the domestic sphere in her New England environment, and Graham seems to have perceived this ambiguity in the poetess in a particularly acute manner. She also 
projected her own struggles with a patriarchal and deeply religious environment on to her depiction of the poet's desire to break free: the piece is built around a system of oppositions, a pattern of obstacles (both interior and exterior) to the artist's "free, joyful expression," and the act of overcoming these obstacles. Here again, Graham echoes Zarathustra when he concludes the second section of "Old and New Tablets" with the following words: "For must there not exist that over which one dances and dances away? Must there not exist, for the sake of the light and the lightest, moles and heavy dwarves?" (Nietzsche, 2005 171) The presence of what Nietzsche calls "the Spirit of Heaviness" (Nietzsche 2005, 171) is necessary to goad the dancer on so she can overcome her limiting circumstances and her personal limitations-the Puritan and patriarchal oppression that has been integrated and endures within her.

In the first act, the scene of "Let us play Yesterday," the group dance that features children and couples enjoying a country dance, incarnates the life force, the playful and whimsical dimension of Dickinson's work, which is opposed to the solo of the man, whose dance is violent and jerky, and who symbolizes, according to Siegel, a "straightlaced father as well as a potential husband" (Siegel 179), the figure of patriarchal oppression internalized in the female creator's mind, conditioned by Puritanism. The first act ends on the poem "I'm sorry for the Dead-Today- ", which refers to playing in the sunshine ("A Wonder if the Sepulchre / Don't feel a lonesome way- / When Men-and Boys-and Carts-and June, / Go down the Fields to "Hay"'last stanza) but which announces the presence of the death force that threatens all this playful activity. In her autobiography, Isadora Duncan shares her struggles with the Puritan streak in her, which, as she explains, is common to all Americans:

I was still a product of American puritanism-whether due to the blood of my pioneer grandfather and grandmother, who crossed the Plains in a covered wagon in '49, cutting their road through virgin forests over the Rocky Mountains and across the burning plains, sternly keeping off or battling with the hordes of hostile Indians, or my Scottish blood on my father's side, or whatever it was-the land of America had fashioned me as it does most of its youth,-a Puritan, a mystic and a striver after the heroic expression rather than any sensual expression whatever, and I believe that most American artists are of the same mould. Walt Whitman, in spite of the fact that his writings were once prohibited and classed as undesirable literature, and in spite of his frequent proclaiming of the joys of the body, is at heart a Puritan and so are most of our writers, sculptors and painters (Duncan 63-64).

15 Martha Graham experienced a similar struggle, which she represented in Letter to the World through the figure of the Ancestress, ${ }^{27}$ which was inspired by her greatgrandmother:

My great-grandmother went from Virginia to Pennsylvania, her family in search of good soil to till. The Pioneering Woman in Appalachian Spring is modeled upon my great-grandmother as is the Ancestress in Letter to the World. She terrified me. She was very beautiful and was always very still. What her father did, and what was passed down in family lore, was wear his best Sunday shirt to do his farming in the belief in the nobility of physical labor, and before he did any work, she had to be sure to iron it each morning (Graham, 1991 232).

16 The Ancestress appears in the second act, "The Postponeless Creature," the embodiment of rigidity and death which stifles all the joyful life bursting in the first act; the dancers of the group dance return to the stage in mourning clothes, and the Ancestress chases "The One who Dances" until she finally catches her. The lover is powerless to drive this creature away, and "The One who Speaks" is finally the one who 
manages to do so by reciting one of Dickinson's most blasphemous poems, "The Bible is an Antique volume / Written by faded Men" (F1577). Recalling her role as the Ancestress in Letter to the World, Jane Dudley remembers that "Martha really felt that Puritanism was the death element in life, and sexuality was the life element in life" (Helpern 17). In Letter to the World, the "life element," the life-affirming "free, joyful action" that feeds creativity and allows free expression is associated to childhood in Acts One and Three. Act Three, "The Little Tippler," presents a playful Dickinson: Graham's choice of costume echoes the frequent gender shifts in Dickinson's poems about childhood. As Denby notes, "The heroine herself appears at one point in a funny dress with trousers under it, and plays games with herself like a schoolgirl, even upsetting the bench and doing happy stunts on it" (Denby 54). The trousers can be a reference both to the type of undergarments worn in the nineteenth century as well as to a form of cross-dressing which is frequently encountered in Dickinson's poems: in poem F1096 "A narrow Fellow in the Grass," the speaker changes gender when reminiscing about the days of childhood ("when a Boy and Barefoot," line 10) just as Dickinson compares herself to a boy "singing" "by the Burying Ground" in one of the letters to Higginson, which makes it most clear that her "scared-little-girl" persona is nothing but a pose. ${ }^{28}$ In the poem "I'm 'wife'-l've finished that" (F225), the power associated to the newly granted title of "wife" is also expressed in masculine terms through the insertion of the figure of the "Czar" in the third line ("I'm 'wife'-I've finished that - / That other state- / I'm Czar, I'm 'Woman' now- "). We can easily see therefore how Graham would have been inspired by this kind of "gender trouble" in her own conception of masculine femininity. Act Three is also the one in which sexual desire is expressed in the most playful manner: in the scene entitled "Dear March, come in," a duet with Merce Cunningham, the sexual innuendo contained in the invitation to March (portrayed as a man who has been travelling for a long time in the poem) to "come upstairs" with the speaker ("Oh March, Come right upstairs with me"), who has "so much to tell," is mirrored in the choreography when "The One who Dances," leaning back on the bench (which symbolizes transgression-the place where the naughty child gets sent to when (s)he is punished)-does a series of contractions and a wide straddle split, while "March" demonstrates his virile strength through a series of "March jumps." For Graham and for Dickinson, childhood is represented as the time when all sorts of metamorphoses are allowed in the form of cross-dressing, playful make-believe, disguise-a time when free expression is possible, and when creativity expresses itself unfettered by the obligations that weigh on the adult. As in the end of Act Two, the child appears as the figure most able to counter the mortiferous influence of Puritanism. The poem used to drive the Ancestress away in Act Two is part of the series of poems in which the speaker adopts the playful mask of the child to get away with blasphemy-such as F1752: "God is indeed a jealous God," for example, where God is vexed because the children would rather play with each other than with Him.

17 The fact that the lover is incapable of driving the Ancestress away shows that these two figures are potential threats to the woman writer. In the fourth act, the choreography of the pas de deux with the lover echoes ominously the pas de deux with the Ancestress in Act Two, as Marcia Siegel explains:

She doesn't embrace the man, she permits herself to be embraced by him, from behind, in an echo of the Ancestress' clenching grip. Her motions become smaller, the phrase shorter, the gesture more tense. Clasping his hand, she keels over, corpse-like, and is pulled upright. The dance culminates in a strange lift-the lover 
collects Emily, who holds her body long and narrow and tight; he supports her stiffarmed, horizontally across his midsection, and whirls around with her very fast. This is another graphic example of Graham's puritanism-she portrays the moment of sexual ecstasy with rigid bodies; the dancers are prevented by the mechanics of the thing they're doing from giving in to their pleasure and letting go of their reserve. When he puts her down they stand embracing for a moment. The Ancestress comes up behind them and, using her hand like a machete, chops them apart (Siegel 182). then, like Duncan, Graham acknowledges that in spite of her efforts and groundbreaking quest to free female movement, she is still a Puritan at heart. The struggle against this internalized Puritan streak contaminates her choreography, which articulates her desire to break free from the shackles of Puritanism and its overwhelming presence, which stifles the expression of eroticism and desire. The last poem read by "The One who Speaks" in this act is Dickinson's "I'm 'wife'-I've finished that" (F225), in which the presence of the husband is designated as a "soft Eclipse"; in Dickinson's poem, female identity is divided into several states-girl, wife, woman-and the poem offers a reflection on the "power" granted to women in marriage. All these states are represented as roles to be played (as signaled by the use of quotation marks for "wife" or "woman") as a performance of various modes of femininity; Graham shrewdly reproduced this fragmentation of female identity in her ballet by making each character-even men-a part of Dickinson's identity.

According to Lamothe, "what Graham found in Nietzsche was inspiration for dancing religion-that is, for presenting dance, in her dances, as capable of revaluing the hostility toward bodies, female bodies in particular, that she believed Americans had inherited from Christian belief and practice" (Lamothe 8). Graham was profoundly inspired by Nietzsche's revaluation process, Umwertung, in choreographing Letter to the World, which explores and revalues the weight of Puritanism on female identity through the figure of Emily Dickinson; but the ballet is also a form of self-exploration, where Graham examines her own struggle with the Puritan tradition. The final solo, "Letter to the World," showcases the female artist's struggle to impose her own voice and establish her artistic legacy in a Puritan patriarchal world. The solo exemplifies Graham's use of Nietzschean Umwertung in the sense that it is also a choreographic experiment, where Graham deploys her trademark style: the dramatic use of fabric and costumes to express tension or elation, ${ }^{29}$ in a sartorial reenactment of the dichotomy between constraint and release, as well as Graham's signature technique (using the floor, flexed feet, contraction and release), revalue what is considered beautiful movement, and beautiful dancing by a woman.

\section{Conclusion} As the final solo of Letter to the World shows, Graham's "remedy" to the priestly values of Puritanism is a Whitmanian celebration of the sacredness of the body. Graham's quest for truth and physical morality is both Nietzschean and Whitmanian, and this is particularly perceptible in her conception of American democracy, in her representation of the individual and the collective. In his article "Hair, Feet, and Connectedness in 'Song of Myself," Taylor Hagood proposes to read Whitman's conception of “individuality versus democracy" 
through the way he uses the head and the feet as connection points, the circulation along vertical and horizontal axes and the position of the body, particularly in "Song of Myself":

One key to understanding Whitman's complicated presentation of "individuality versus democracy" lies in his depiction and positioning of body in "Song of Myself." Particularly important is his alignment of the human body along horizontal and vertical axes. Whitman portrays the head and the feet as the body's extreme connection points (Hagood 25).

21 In her autobiography, Graham evokes a similar circulation of energy in the body, and also posits the head and the feet as "the body's extreme connection points": "the awakening starts in the feet and goes up. Through the torso, the neck, up, up, through the head, all the while releasing energy" (Graham, 1991 122). The Nietzschean opposition between Apollo and Dionysus, between the high and the low connection points that Hagood identifies in Whitman's Leaves of Grass, stands for the poet's conception of the American democratic ideal, the verticalness of American individuality and the horizontalness of democracy. Graham makes a similar use of verticalness and horizontalness in Letter to the World, with her use of the solo after many group scenes: the solo symbolizes the individual's freedom, the liberation of the woman writer (and the female dancer) from all the constraints imposed by a patriarchal Puritan society introduced before in the ballet, and it allegorizes the individual's freedom as exemplum. The liberated female creator becomes an allegory of female liberation, a model, but also an allegory of freedom, of the struggles that all American creators face in the creative process, in which they have to contend (and fight) with their inner Puritan, all the priestly values that they have integrated. In that sense, Graham's representation of the individual and the collective is very close to Whitman's in Leaves of Grass. Like Whitman, she is seeking to establish an American ritual, in which all the different facets come together as one in a celebratory fashion. As Amanda Porterfield explains, dance-whose origins, anthropologically, are associated with the sacred-establishes a form of ritual:

What modern dance offered Americans was ritual, a form of cultural expression that acted out in public performance the personal experiences of its viewers. Many religions, especially "primitive" ones, have found ritual expression through dance. The choreographers of modern dance gleaned meaningful patterns in the personal lives of their contemporaries and worked to formalize those patterns in the art of dance [...]. [R]itual refers to the formalization of human activity and emotion. A choreography interprets ordinary life in formal patterns invested with symbolic weight and performed as if they could be repeated. A particular dance may be seen only once and still qualify, in the eyes of a viewer, as a religiously significant formal expression of human activity (Porterfield 192-193).

Letter to the World, like American Document two years before, establishes an American ritual in its very revaluation of Americanness-which is articulated in the revaluation of what beautiful movement is, by focusing on the body, its physicality and its strength, by revisiting and reinterpreting the life and work of an iconic writer, and also by representing this struggle with Puritanism which, according to Duncan, is common to all American artists. Through dance, through this ritual celebrating the sacredness of the body and affirming life through movement, the spectators and artists on stage all come together in an American democratic ritual. 


\section{BIBLIOGRAPHY}

“Martha Graham's Recital.” The New York Times, March 4, 1929.

“Martha Graham offers a revival." The New York Times, May 12, 1944.

“Penitence and Temptation in a Martha Graham Work." The New York Times, October 10, 1989.

ARMITAGE, Merle. Martha Graham, The Early Years. New York: Dance Horizons, 1968.

BANES, Sally. Writing Dancing in the age of Postmodernism. Hanove: Wesleyan University Press, 1994.

BLONDEL, Éric. Nietzsche, le corps et la culture: la philosophie comme généalogie philologique. Paris: Presses Universitaires de France, 1986.

BURT, Ramsay. "Dance, Gender and Psychoanalysis: Martha Graham's Night Journey." Dance Research Journal 30, no 1, 1998.

CHARCOT, Jean-Martin, and RICHER, Paul, Les Démoniaques dans l'art, Paris: Adrien Delahaye et Émile Lecrosnier, 1887.

CHEVRIER-BOSSEAU, Adeline. “Dance in Walt Whitman's Leaves of Grass: Haptic Connectedness and Lyric Choreography." Whitman, Feuille à feuille. Eds. Agnès Derail and Cécile Roudeau. Paris: Éditions Rue d'Ulm, 2019, p. 21-37.

COPELAND, Roger, and COHEN, Marshall. What is Dance? Oxford: Oxford University Press, 1983. DENBY, Edwin. Dance Writings and Poetry. Ed Robert Cornfield. New Haven: Yale University Press, 1998.

DICKINSON, Emily. The Poems of Emily Dickinson. Variorum Edition. Ed. R. W. Franklin, Cambridge, MA.: The Belknap Press of Harvard University Press, 1998.

DICKINSON, Emily. The Letters of Emily Dickinson. Eds. Thomas H. Johnson and Theodora Ward. Cambridge, MA: The Belknap Press of Harvard University Press, 1958.

DUNCAN, Isadora. My Life. New York: Liveright Publishing, 2013.

FOULKES, Julia L. Modern Bodies: Dance and American Modernism from Martha Graham to Alvin Ailey. Chapel Hill: University of North Carolina Press, 2002.

FRALEIGH, Sondra H. Dance and the Lived Body, A Descriptive Aesthetics. Pittsburgh: University of Pittsburgh Press, 1987.

FRANKO, Mark. Martha Graham in Love and War, The Life in the Work. Oxford: Oxford University Press, 2012.

FRANKO, Mark. Dancing Modernism, Performing Politics. Bloomington: Indiana University Press, 1995.

FRANKO, Mark. "Emotivist Movement and Histories of Modernism: The Case of Martha Graham." Discourse, vol. 13, no. 1, 1991, p. 111-128.

FREEDMAN, Russell, Martha Graham, A Dancer's Life. New York: Clarion Books, 1998.

GOTTSCHILD, Brenda D. Digging the Africanist Presence in American Performance, Dance \& Other Contexts. Westport, CT: Greenwood Press, 1996.

GRAHAM, Martha. Primitive Mysteries. 1931. 
GRAHAM, Martha. El Penitente. 1940.

GRAHAM, Martha. Letter to the World. 1940.

GRAHAM, Martha. Appalachian Spring. 1944.

GRAHAM, Martha. Blood Memory, An Autobiography. New York: Doubleday, 1991.

GRAHAM, Martha. The Notebooks of Martha Graham. New York: H. B. Jovanovich, 1973.

“A Modern Dancer's Primer for Action.” Dance: A Basic Educational Technique. Ed. Frederick Rand Rogers. New York: Macmillan, 1941, p. 178-187.

HAGOOD, Taylor. "Hair, Feet, Body and Connectedness in 'Song of Myself." Walt Whitman Quarterly, vol. 21, no. 1, 2003, p. 25-34.

HAWTHORNE, Nathaniel. Twice-Told Tales. New York: Random House, Modern Library Classics, 2001.

HELPERN, Alice, ed. Martha Graham, special issue of Choreography and Dance, An international Journal, vol. 5, part 2, London: Routledge, 1999.

JOWITT, Deborah. Time and the Dancing Image. Los Angeles: University of California Press, 1988.

KILLINGSWORTH, Jimmie. Whitman's Poetry of the Body; Sexuality, Politics, and the Text. Chapel Hill: University of North Carolina Press, 1989.

KIRSTEIN, Lincoln. Dance, A Short History of Theatrical Dancing. Westport, CT: Greenwood Press, 1970.

LAMOTHE, Kimerer. Nietzsche's Dancers: Isadora Duncan, Martha Graham and the Revaluation of Christian Values. New York: Palgrave Macmillan, 2006.

LAMOTHE, Kimerer. Why We Dance: A Philosophy of Bodily Becoming. New York: Columbia University Press, 2015.

MURPHY, Jacqueline Shea. The People Have Never Stopped Dancing: Native American Modern Dance Histories. Minneapolis: University of Minnesota Press, 2007.

NIETZSCHE, Friedrich. Twilight of the Idols. Translated from German by R. J. Hollingdale.

Harmondsworth: Penguin, 1968.

NIETZSCHE, Friedrich. The Gay Science. Translated from German by W. Kaufman. New York: Random House, 1974.

NIETZSCHE, Friedrich. On the Genealogy of Morals \& Ecce Homo. Translated from German by W. Kaufman. New York: Vintage Books, 1989.

NIETZSCHE, Friedrich. La Naissance de la tragédie. Translated from German by Hans Hildenbrand and Laurent Valette. Paris: Christian Bourgeois, 1991.

NIETZSCHE, Friedrich. Thus Spoke Zarathustra. Translated from German by G. Parkes. Oxford \& New York: Oxford University Press, 2005.

PORTERFIELD, Amanda. Feminine Spirituality in America: From Sarah Edwards to Martha Graham. Philadelphia: Temple University Press, 1980.

ROSEMAN, Janet L. Dance was Her Religion: The Spiritual Choreography of Isadora Duncan, Ruth St Denis and Martha Graham. Prescott: Hohm Press, 2004.

ROWLANDSON, Mary. Narrative of the Captivity, Sufferings and Removes of Mrs. Mary Rowlandson. Clinton: Ballard \& Brynner, 1853. 
RUYTER, Nancy Lee Chalfa. The Cultivation of Body and Mind in Nineteenth-Century American Delsartism. Westport, CT: Greenwood Press, 1999.

SHAWN, Ted. The American Ballet. New York: Henry Holt \& Co, 1926

SIEGEL, Marcia B. The Shapes of Change, Images of American Dance. Boston: Houghton Mifflin, 1979.

SIMONARI, Rosella. “The Ancestress Figure: Puritanism in Martha Graham's Choreography.”

European Journal of American Culture, vol. 33, no. 2, 2014, p. 131-145.

STODELLE, Ernestine. Deep Song: The Dance Story of Martha Graham. London: Schirmer Books, 1984.

WAGNER, Ann Louise. Adversaries of Dance from the Puritans to the Present. Urbana: University of Illinois Press, 1997.

WHEELER, Mark. "The Orient in America: Fertile Soil for Martha Graham.” Martha Graham, special issue of Choreography and Dance, An international Journal. Ed. Alice Helpern, vol. 5, part 2, London: Routledge, 1999, p. 41-52.

WHITMAN, Walt. Leaves of Grass and Other Writings. Ed. Michael Moon. New York: Norton, 2002.

\section{NOTES}

1. Graham's father was a doctor (a psychiatrist), while Duncan's family was more bohemian and arts-oriented (her parents divorced when she was young, she was raised by her pianist mother, and Duncan started making a living as a dancer and a dance teacher at a young age).

2. After seeing Ruth Saint Denis perform, a couple of years after her family moved to California, Graham decided to become a dancer and enrolled in the Denishawn school.

3. Duncan started her dance training as a child, but she rebelled against the classical training she received. Graham, on the other hand, learned dance as a young adult. Both women's dance training and careers were unorthodox according to the conventions of classical dance; they shared a profoundly organic and intuitive approach to movement, and they each created their own idiosyncratic style, setting them apart as pioneers and rebels.

4. Her biographer Russell Freedman explains that "Martha and her sisters were brought up strictly, with daily prayers, Sunday-school training, and regular attendance at their local Presbyterian church. The girls were expected to be polite, respectful, and obedient, to sit straight at the dinner table, to stand when spoken to by an adult, and to wear spotless white gloves when they went to church" (Freedman 17). Graham herself remembers that her great-grandmother, on whom the character of the Ancestress in Letter to the World is based, "tried to make proper young ladies out of all of us, which never really interested me" (Graham, 199124$).$

5. These ballets correspond to her "American" period: at the beginning of her career, Graham explored American themes, before turning to Greek mythology and biblical or religious references (such as Judith or Joan of Arc) for inspiration from the second half of the 1940's onward.

6. In her autobiography, Graham repeatedly professes her fascination for sexuality and her refusal to be ashamed of it: "All of my life I have been a devotee of sex, in the right sense of the word. Fulfillment, as opposed to procreation [...]. No wonder the Graham girls were always considered a little fast" (Graham 1991, 160). "As far as sex is concerned, I think that it is quite beautiful. [...] I like the beauty of the body and I enjoy what it expresses about life. For that reason I don't deny sex. I've only glorified in the beauty of it. Only hidden things are obscene. I think that censorship is the height of vanity" (Graham, 1991211$).$

7. Graham choreographed a ballet based on The Scarlet Letter in 1975, a piece which centers around the character of Dimmesdale, a role she created for Rudolph Nureyev. The plot of Heretic 
also echoes Emily Dickinson's own stance on religion, at odds with her family and the religious community of Amherst: "They are religious-except me-and address an Eclipse, every morning -whom they call their "Father"' (L261 to Th. W. Higginson, April 1862). This "heretic" stance probably resonated deeply with Graham.

8. The program referred to "strong, free, joyful action" (see Lamothe 2006, 8).

9. "Miss Ruth" is Ruth Saint Denis, another major American dance pioneer and Graham's teacher and mentor.

10. Duncan proclaimed in her autobiography that "the supreme poet of our country is Walt Whitman. I have discovered the dance that is worthy of the poem of Walt Whitman. I am indeed the spiritual daughter of Walt Whitman" (21).

11. In his manifesto The American Ballet, Ted Shawn mentions Walt Whitman in the prologue and places the new American dance under the poet's tutelage: "the dance of America will be as seemingly formless as the poetry of Walt Whitman, and yet like Leaves of Grass it will be so big that it will encompass all forms. Its organization will be democratic, its fundamental principles, freedom \& progress; its manifestation an institution of art expression through rhythmic, beautiful bodily movement, broader and more elastic than has ever yet been known" (Shawn, "Foreword"). Lincoln Kirstein also references Whitman as a model of Americanness in his Short History of Theatrical Dancing and explains that Duncan modeled her dance on his conception of America as a "breathless, expansive, divine new continent" (Kirstein, 265).

12. Whitman also wrote a series of articles entitled "Manly Health and Training," published in The New York Atlas in the middle of the nineteenth century, in which he urges sedentary menstudents or clerks-to go out and exercise outdoors, since being confined indoors for hours is detrimental to their health.

13. Also reiterated in her autobiography: "Movement never lies" (Graham, 1991 122).

14. Like Whitman and Duncan before her, Graham was exposed to American Delsartism, which was extremely popular towards the end of the $19^{\text {th }}$ century; François Delsarte's theories about the body were brought to the new continent by his disciple Steele Mackaye, and they soon gained momentum. Duncan's precursors, Genevieve Stebbins and Henrietta Hovey, gave many lectures on the subject for high-society women, and Delsartism was often associated with the growing hygienist movement. Graham's father being a psychiatrist, he would most certainly have known about Delsarte's contention that every psychological state is translated through physical attitudes-a conclusion his French colleague Jean-Martin Charcot had also come to in his study of hysterical patients and had documented in Les Démoniaques dans l'art. Graham was also taught about Delsarte in the Denishawn School of dance, where his theories were part of the curriculum. For further discussion of American Delsartism, see Nancy Lee Chalfa Ruyter, The Cultivation of Body and Mind in Nineteenth-Century American Delsartism.

15. Increase Mather refers to the "disorderliness of dancers" in his "Arrow Against Profane and Promiscuous Dancing Drawn out of the Quiver of the Scriptures" (1684), and compares dance to the unruly and wild movement of mad people: "And truly such affected levity, and antick behaviour, when persons skip and fling about like Bedlams, as they say, Dancers are wont to do; is no way becoming the gravity of a Christian" (quoted by Wagner 50).

16. Another passage of "the Fourth Remove" also refers to their dance in that way: "they had sung and danced about her (in their hellish manner)" ("Fourth Remove," Rowlandson 15).

17. "On the shoulders of a comely youth uprose the head and branching antlers of a stag; a second, human in all other points, had the grim visage of a wolf; a third, still with the trunk and limbs of a mortal man, showed the beard and horns of a venerable he-goat. There was the likeness of a bear erect, brute in all but his hind legs, which were adorned with pink silk stockings" (Hawthorne 38).

18. As Jacqueline Shea Murphy delineates in her chapter on Graham and Indians, Graham integrated Native American movement in her technique: 
Dancers from the early 1930s note the influence this exposure to Southwest American Indian land and culture had on Graham's class work and choreography. Dancer Marie Marchowsky writes of "the contraction and release principle," described as the "fundamental source" of Graham's early course work: "The exercises were primitive: legs and feet parallel, hands cupped, feet flexed as if rooted into the earth. The movement was influenced by American Indian dances -a source of inspiration to Martha" (151).

19. In her "Affirmations," she writes that "the Indian dance [...] is for awareness of life, complete relationship with that world in which he finds himself; it is a dance for power, a rhythm of integration' (Armitage, 99). Both Duncan's inclination towards Ancient Greek aesthetics and physical morality, and Graham's idealization of primitive cultures stem from their reading of Jean-Jacques Rousseau's Discourse on Inequality, which represents the primitive state as ideal and free from moral corruption. The cliché of the "good savage" that permeates both women's philosophy of the body shows that their approach to the French philosopher's works was not scholarly, but, once again, intuitive and not necessarily situated in a broader academic philosophical context. Duncan was also deeply influenced by Rousseau's Émile in her own conception of pedagogy-letting the children come up with their own way of moving, refusing to impose any restrictions on the children's creative impulses, rejecting imitation, for exampleand by extension, so were other pioneers of American dance such as Graham, who was influenced by Duncan (this is reflected in her use of maieutics, for example).

20. "Martha Graham offers a revival," The New York Times, May 12, 1944.

21. For further discussion of the poem, see my article "Dance in Walt Whitman's Leaves of Grass," 26-27.

22. In this endeavor, Graham echoes Emerson's plea for self-reliance, and argues for an indigenously American tradition which does not hide in the shadow of the European tradition.

23. Graham was well-versed in Oriental philosophy, Buddhism and yoga, which she mentions several times in her autobiography as major influences on her trademark technique; the chakra located in the pelvis is the first, or "root," chakra, the source of the life force and sexual energy in the body-a particularly important chakra for women in kundalini yoga, since it connects women to the Earth and to what is perceived as the essence of femininity-creative, generative power.

24. "The action is built on the legend rather than on the facts of her life, and the scene is laid in the shadow world of her imagination as set forth in her poems, rather than the real world of Amherst where she lived" (program for Letter to the World, 1941).

25. Emily Dickinson, letter to Th. W. Higginson, L261, April 25, 1862: "Thank you for the surgeryit was not so painful as I supposed."

26. Dickinson's third letter to Higginson, written on June 7, 1862, lets us understand that Higginson warned the poetess against publishing her work as it was: "I smile when you suggest that I delay 'to publish'-that being foreign to my thought, as Firmament to Fin."

27. See Rosella Simonari's article on "The Ancestress Figure" in Appalachian Spring and Letter to the World.

28. "and so I sing, as the Boy does by the Burying Ground-because I am afraid."( L261, April 25, 1862). This is the letter in which Dickinson poses as some sort of wild child, having for companions "Hills-and the Sundown-and a Dog-large as myself, that my father bought me," and shrinking from reading Spofford's "Circumstance" or Whitman's poetry because they are either too scary or "disgraceful."

29. Barbara Morgan's photograph from the final solo capturing the kick is a particularly good illustration of this. 


\section{ABSTRACTS}

This paper will explore Graham's revaluation of morality, as well as her Whitman-inspired conception of "physical morality" promoting the free expression of the body, and her conception of the universal beauty of the body performing true movement, free from the stifling falseness of Puritan conventions. Influenced by Nietzsche, Graham opposed the repressive forces of a Puritan "priestly mode of valuation" to a life-affirming, joyful urge in the soul that fosters creativity and doesn't devalue the body. This opposition will be particularly examined in her use of Nietzschean Umwertung in her ballet Letter to the World, which was inspired by the life and work of Emily Dickinson.

Cet article s'intéressera à la manière dont Graham, inspirée par Nietzsche et Walt Whitman, revisite la notion de moralité, et en particulier d'une «moralité physique » où la vertu s'incarne aussi dans le corps, et non seulement dans l'esprit - une vertu qui viendrait de l'expression libre et « vraie » du corps, débarrassé du fardeau et de la fausseté des conventions puritaines. Comme Whitman et Nietzsche, Graham met en scène cette opposition entre les forces répressives du puritanisme et la pulsion de vie, créatrice et vertueuse, et refuse une séparation du corps et de l'esprit dans la conception de la morale ou de la vertu. Cette opposition sera particulièrement examinée dans l'interprétation que Graham donne de la notion nietzschéenne d'Umwertung dans son ballet Letter to the World, inspiré de la vie et de l'œuvre d'Emily Dickinson.

\section{INDEX}

Keywords: Martha Graham, dance, Emily Dickinson, Nietzsche, Puritanism, religion, Walt Whitman

Mots-clés: Martha Graham, danse, Emily Dickinson, Nietzsche, puritanisme, religion, Walt Whitman

\section{AUTHOR}

\section{ADELINE CHEVRIER-BOSSEAU}

Université Clermont Auvergne 